\title{
Discussing the Costs and Financial Burden of Cancer and its Treatment: A Systematic Review of Clinical Guidelines
}

\section{Anupriya Agarwal ( $\sim$ anupriya.agarwal@ctc.usyd.edu.au )}

NHMRC Clinical Trials Centre https://orcid.org/0000-0001-6111-8430

Ann Livingstone

NHMRC Clinical Trials Centre

Deme J Karikios

NHMRC Clinical Trials Centre

Martin R Stockler

NHMRC Clinical Trials Centre

Philip J Beale

The University of Sydney

Rachael L Morton

NHMRC Clinical Trials Centre

Research article

Keywords: Systematic review, guidelines, cost discussions, costs of care, cancer costs, financial toxicity, financial burden.

Posted Date: April 5th, 2021

DOI: https://doi.org/10.21203/rs.3.rs-390553/v1

License: (c) (1) This work is licensed under a Creative Commons Attribution 4.0 International License.

Read Full License 


\section{Abstract}

\section{Background}

Optimising the care of individuals with cancer without imposing significant financial burden related to their anticancer treatment is becoming increasingly difficult. The American Society of Clinical Oncology (ASCO) has recommended clinicians discuss costs of cancer care with patients to enhance shared decision-making. We sought information to guide oncologists' discussions with patients about these costs.

\section{Methods}

We searched Medline, EMBASE and clinical practice guideline databases from January 2009 to 1 June 2019 for recommendations about discussing the costs of care and financial burden. Guideline quality was assessed with the AGREE-II instrument.

\section{Results}

Twenty-seven guidelines met our eligibility criteria, including 16 from ASCO (59\%). 21 of 27 (78\%) guidelines included recommendations about discussion or consideration of treatment costs when prescribing, with information about actual costs in four (15\%). Recognition of the risk of financial burden or financial toxicity was described in $81 \%(22 / 27)$ of guidelines. However, only nine guidelines $(33 \%)$ included information about managing the financial burden.

\section{Conclusions}

Current clinical practice guidelines have limited information to guide discussions regarding costs of anticancer treatment and management of financial burden. This limits the ability of patients to control the costs of treatment, and of the healthcare team to reduce the incidence and severity of financial burden. Current guidelines recommend clinician awareness of price variability and high costs of treatment. Clinicians are recommended to explore cost concerns and address financial worries, especially in high risk groups. Future guidelines should include advice on facilitating cost transparency discussions, with provision of costs information and resources.

\section{Background}

In the United States, the estimated national expenditure on cancer care in 2017 was \$147.3 billion (1), and this is projected to increase with an ageing population and rise in cancer prevalence. Additionally, the advent of personalised medicine and availability of newer therapies come at increasing costs, especially as many are prescribed lifelong. As healthcare costs for cancer are higher than for other conditions (2), discussions regarding expenses are relevant and necessary to allow timely interventions that reduce the risk of financial burden. 'Financial toxicity', or treatment-related financial harm of cancer care has been reported in up to one in four patients with cancer (3). This can have unintended consequences due to 
patients' attempts to reduce costs by non-adherence to medication and missing healthcare appointments $(4,5)$. Patients who reported higher self-rated financial burden had poorer cancer outcomes, lower qualityof-life scores, and less satisfaction with care (6).

Recognition of cancer-related financial burden has led to initiatives towards improving price transparency and value-based care in the clinical setting. In recent years, cancer organisations have recommended greater transparency about the costs of treatment. The American Society of Clinical Oncology's Guidance Statement on the Cost of Cancer Care (7) recommends 'patient-physician discussions regarding the cost of care are an important component of high-quality care'. Health care providers, especially oncologists, have a greater responsibility to include discussion of costs in their communication with patients.

Enhanced patient-physician communication may heighten physicians' awareness of financial issues and thereby help ensure patients are prescribed the most cost-effective medicines (7). Physicians can also play a key role in educating patients to make appropriate and affordable decisions regarding their out-ofpocket costs.

A review of patient-physician costs communication indicated that the majority of patients wanted to discuss costs with their oncologists (8-10) and most physicians felt it was their responsibility. However, financial issues were not frequently addressed, and more than $70 \%$ of oncologists felt uncomfortable with such communication (11), largely due to lack of appropriate information to facilitate the discussion. Additionally, patients commonly deferred cost discussions with their oncologist until they were already experiencing financial burden (4). However, when patients did talk about costs with their clinician, it led to lower out-of-pocket costs (12). Clinical practice guidelines can assist physician education to direct discussions of costs and management of financial burden.

Therefore, we conducted a systematic review of published clinical practice guidelines to identify information available to oncologists regarding the discussion of costs; and the detection and management of financial burden. The motivating goal for this review was to provide a summary of existing guidelines about the discussion of costs and management of financial burden in cancer care. In addition, the review would identify gaps in the information available to guide future research and guideline development.

\section{Methods}

The Preferred Reporting Items for Systematic Reviews and Meta-Analyses (PRISMA)(13) checklist was used to guide this review.

\section{Data sources and guideline selection}

We conducted a systematic literature search of the following databases: PubMed/Medline, Embase, the National Guideline Clearinghouse within the Agency for Healthcare Research and Quality (AHRQ), Turning Research Into Practice (TRIP) database, Scottish Intercollegiate Guidelines Network (SIGN) and 
International Guidelines Network (GIN). We searched guidelines from the following organisations: American Society of Clinical Oncology (ASCO), National Comprehensive Cancer Network (NCCN), Canadian Medical Association (CMA), and Cancer Australia. We limited our search to guidelines published after January 2009 following publication of the ASCO Guidance Statement for Costs of Cancer Care (7), which first proposed discussion of costs in the clinical setting. All guideline searches were finalised on 15 July 2019. Full details of the search strategy are in Table 1A in the Appendix.

\section{Study selection}

Results from the five databases were downloaded into Covidence (14), a Cochrane reference management tool for systematic reviews. Two reviewers, AA and DK, independently screened the titles and abstracts. Studies considered eligible underwent full text review by AA and DK, and disagreements regarding inclusion were resolved by consensus with a third reviewer (RLM).

We selected guidelines that provided recommendations about the discussion of costs, the detection of financial burden, or the management of financial burden, in people with cancer. The study inclusion criteria were: 1) clinical practice guidelines endorsed by a national government or professional association, including position statements by professional associations; 2 ) articles about the management of advanced cancer; 3) guidelines intended for health professionals; 5) guidelines published from June 2009. We excluded guidelines that were related to the management of nonmelanoma skin cancers, and guidelines that only included the discussion of cost-effectiveness analyses that do not apply directly to patients. No language restriction was applied.

\section{Guideline quality assessment}

Two reviewers (AA and AL) independently applied the Appraisal of Guidelines Research and Evaluation (AGREE-II) instrument (15) to determine the methodological quality of each included guideline. The AGREE-II instrument is comprised of 23 items organised in six domains: 1 . scope and purpose; 2. stakeholder involvement; 3 . rigour of development; 4 . clarity of presentation; 5 . applicability; and 6. editorial independence. Each of the 23 items is rated on a 7-point Likert scale. Scores were calculated as a percentage (range $0-100 \%$ ), and discrepancies between reviewers $\geq 4$ points for an individual item were resolved by consensus. Guidelines that scored at least $60 \%$ in all domains were considered to be of adequate quality, a criterion that has been utilised in previously published guideline appraisals (16-18).

\section{Data extraction}

We extracted the following information from clinical practice guidelines:

1. Consideration and/or discussion of costs, including provision of cost estimates when making decisions regarding treatment.

2. Recommendations for screening for financial burden or stress in patients undergoing management of cancer.

3. Recommendations for management of financial burden or financial stress in patients, including provision of support services or further information available to patients. 
We summarised and collated the key recommendations in the guidelines.

\section{Results}

\section{Literature search results}

The literature search yielded 484 studies that underwent screening and analysis (see Fig. 1, PRISMA flowchart). After full text analysis we identified 27 guidelines that satisfied the eligibility criteria (Table 1). All included guidelines were published in English. The guidelines included in the full text analysis were from the following four groups: ASCO, SIGN, Canadian Association of Psycho-Oncology (CAPO), and NCCN. 
Table 1

Guidelines included in the review

\section{Guideline}

$\begin{array}{ll}\text { Guideline } & \text { First } \\ \text { organisation/ } & \text { author, } \\ \text { society } & \begin{array}{l}\text { publication } \\ \text { year }\end{array}\end{array}$

United States

American Society of Clinical Oncology Guidance Statement: The Cost of Cancer Care

ASCO

Meropol et al., 2009

American Society of Clinical Oncology Clinical Practice Guideline Update on Chemotherapy for Stage IV Non-Small Cell Lung Cancer

ASCO

Azzoli et al., 2009

American Society of Clinical Oncology/American Society of Hematology Clinical Practice Guideline Update on the Use of Epoetin and Darbepoetin in Adult Patients With Cancer

ASCO/ASH Rizzo et al., 2010

Appropriate Chemotherapy Dosing for Obese Adult Patients With Cancer: American Society of Clinical Oncology Clinical Practice Guideline

ASCO

Griggs et

al., 2012

Screening, Assessment, and Care of Anxiety and Depressive ASCO

Andersen Symptoms in Adults with Cancer: An American Society of Clinical et al., 2014 Oncology Guideline Adaptation

Endocrine Therapy for Hormone Receptor-Positive Metastatic Breast ASCO Cancer: American Society of Clinical Oncology Guideline

Rugo et al., 2016

Patient-Clinician Communication: American Society of Clinical Oncology Consensus Guideline

ASCO

Gilligan et al., 2017

Anti-emetics: American Society of Clinical Oncology Clinical Practice Guideline Update

ASCO

Hesketh et al., 2017

Role of Bone-Modifying Agents in Metastatic Breast Cancer: An American Society of Clinical Oncology-Cancer Care Ontario Focused Guideline Update

Outpatient Management of Fever and Neutropenia in Adults Treated for Malignancy: American Society of Clinical Oncology and Infectious Diseases Society of America Clinical Practice Guideline Update

$\begin{array}{ll}\text { ASCO/CCO } & \text { Van } \\ & \text { Poznak et } \\ & \text { al., 2017 }\end{array}$

ASCO/IDSA

Taplitz et al., 2018

Fertility Preservation in Patients with Cancer: American Society of Clinical Oncology Clinical Practice Guideline Update

ASCO

Oktay et al., 2018

Metastatic Pancreatic Cancer: American Society of Clinical Oncology ASCO Sohal et Clinical Practice Guideline Update al., 2018

Optimizing Anticancer Therapy in Metastatic Non-Castrate Prostate Cancer: American Society of Clinical Oncology Clinical Practice ASCO

Morris et Guideline

Sentinel Lymph Node Biopsy and Management of Regional Lymph Nodes in Melanoma: American Society of Clinical Oncology and al., 2018

Society of Surgical Oncology Clinical Practice Guideline Update 


\begin{tabular}{|c|c|c|}
\hline Guideline & $\begin{array}{l}\text { Guideline } \\
\text { organisation/ } \\
\text { society }\end{array}$ & $\begin{array}{l}\text { First } \\
\text { author, } \\
\text { publication } \\
\text { year }\end{array}$ \\
\hline $\begin{array}{l}\text { Practical Assessment and Management of Vulnerabilities in Older } \\
\text { Patients Receiving Chemotherapy: American Society of Clinical } \\
\text { Oncology Guideline for Geriatric Oncology }\end{array}$ & ASCO & $\begin{array}{l}\text { Mohile et } \\
\text { al., } 2018\end{array}$ \\
\hline $\begin{array}{l}\text { Use of Larynx-Preservation Strategies in the Treatment of Laryngeal } \\
\text { Cancer: American Society of Clinical Oncology Clinical Practice } \\
\text { Guideline Update }\end{array}$ & ASCO & $\begin{array}{l}\text { Forastiere } \\
\text { et al., } 2018\end{array}$ \\
\hline \multicolumn{3}{|l|}{ Europe } \\
\hline Diagnosis and management of colorectal cancer & SIGN & $\begin{array}{l}\text { Steele et } \\
\text { al., } 2011 \\
\text { (revised } \\
\text { 2016) }\end{array}$ \\
\hline Management of lung cancer & SIGN & $\begin{array}{l}\text { Fergusson } \\
\text { et al., } 2014\end{array}$ \\
\hline Management of adult testicular germ cell tumours & SIGN & $\begin{array}{l}\text { Howard et } \\
\text { al., } 2011\end{array}$ \\
\hline Management of epithelial ovarian cancer & SIGN & $\begin{array}{l}\text { Siddiqui et } \\
\text { al., } 2013\end{array}$ \\
\hline Cutaneous melanoma & SIGN & $\begin{array}{l}\text { Brown et } \\
\text { al., } 2017\end{array}$ \\
\hline \multicolumn{3}{|l|}{ Canada } \\
\hline $\begin{array}{l}\text { A Pan-Canadian Clinical Practice Guideline: Assessment of } \\
\text { Psychosocial Health Care Needs of the Adult Cancer Patient }\end{array}$ & CAPO & $\begin{array}{l}\text { Howell et } \\
\text { al., } 2009\end{array}$ \\
\hline $\begin{array}{l}\text { A Pan-Canadian Practice Guideline: Prevention, Screening, } \\
\text { Assessment and Treatment of Sleep Disturbances in Adults with } \\
\text { Cancer }\end{array}$ & CAPO & $\begin{array}{l}\text { Howell et } \\
\text { al., } 2012\end{array}$ \\
\hline $\begin{array}{l}\text { Pan-Canadian Practice Guideline: Screening, Assessment and } \\
\text { Management of Psychosocial Distress, Depression and Anxiety in } \\
\text { Adults with Cancer }\end{array}$ & CAPO & $\begin{array}{l}\text { Howell et } \\
\text { al., } 2015\end{array}$ \\
\hline
\end{tabular}

\section{Themes from guidelines}

We identified three themes (Fig. 2) covered by the guidelines: 1 . discussion of costs; 2 . detection of financial burden; and 3. management of financial burden.

\section{Costs}

Guidelines on discussion of costs were limited to statements recommending consideration and patient awareness of high costs of care when prescribing treatments. 21 of $27(7,19-38)$ guidelines $(78 \%)$ used 
the term 'costs' within their recommendations for patient management. Of these, 16 of 21 guidelines (76\%) stated clinicians should consider costs and cost concerns of patients when prescribing therapy or discussing management options. Four of 21 guidelines $(19 \%)(20,22,25,30)$, all from ASCO, outlined Medicare Part B/D costs to guide clinicians in when making decisions about the choice of therapy. One guideline (NCCN Palliative Care)(38) described how 'earlier palliative care consultations have been associated with reduced healthcare costs for patients with advanced cancer and multiple comorbidities'; and a separate guideline (NCCN Older Adult Oncology)(37) recommended the use of a financial expert to discuss costs and insurance coverage options with the patient.

None of the guidelines contained recommendations or references about communication tools or the use of informed financial consent in the clinic visit. There were no summary statements provided in the guidelines to assist clinicians explain costs. However, there were sample talking points outlined in the Data Supplement to the ASCO Guideline on Systemic Therapy for Patients With Advanced Human Epidermal Growth Factor Receptor 2-Positive Breast Cancer (39) to assist clinicians explaining the costs of therapy, and links to further information about supportive services and costs.

\section{Financial burden}

\section{Recognition of financial burden}

Financial burden was recognised in 22 of 27 guidelines $(81 \%)(7,19,21-24,26-28,30,32-36,40-44)$. All guidelines from SIGN $(n=5)$ contained recommendations to assess financial burden in people with cancer. Financial burden was noted in a single NCCN guideline, Distress Management (36), which recommended that clinicians consider 'financial toxicity' and 'financial worries' as a risk factor for distress. However, none of the NCCN guidelines had referral details for further support services, or management options for patients with financial burden.

Of the guidelines from ASCO, only 11 of $16(69 \%)$ recognised financial burden as a cause of distress. The ASCO guideline on 'Patient-Clinician Communication' recommended clinicians 'explore whether there are any financial constraints' as a core communication skill that must be applied at every visit across the cancer continuum. In four of the ASCO guidelines, the discussion of financial burden was presented in the form of a generic statement: 'When discussing financial issues and concerns, patients should be made aware of any financial counselling services that are available to address this complex and heterogeneous landscape'. However, none of these guidelines detailed any further financial counselling resources or provided further directions of where to find this information.

\section{Management of financial burden}

Management of financial burden was outlined in nine of 27 (33\%) $(21-23,32,40-44)$ guidelines. This was in the form of referral to support services or financial counsellors/experts. Details of support services, for example the MacMillan Cancer Support services (45), were provided in three of the five guidelines from SIGN, with clinicians directed to refer patients to these services. Only three of the ASCO guidelines (19\%; 3 of 16) gave instructions to clinicians regarding management of financial concerns, and 
this was in the form of a 'recommendation to refer to a financial counsellor'. One ASCO guideline, 'Screening, Assessment and Care of Anxiety and Depressive Symptoms in Adults with Cancer' (40), instructed clinicians to provide patients and families with education, verbal and written information regarding the availability of financial support for accommodation, drug costs, and transportation.

\section{Quality assessment}

The AGREE-II domain scores are shown in Table 2A in the Appendix. The mean scores (range) for each of the domains were: scope and purpose $92 \%$ (83-100\%); stakeholder involvement $83 \%$ (67-100\%); rigour of development $84 \%$ (67-98\%); clarity of presentation $94 \%$ (81-100\%); applicability $75 \%$ (58-96\%); and editorial independence $84 \%(79-100 \%)$.

Twenty-four (89\%) guidelines were assessed as 'recommended for use', with appraisal scores of 5 to 7 reflecting guidelines of good to high quality. The other three $(11 \%)$ guidelines were assessed as 'recommended for use with modifications' because scores for their appraisal were lower, primarily due to lack of reporting about their methods or limited representation of important groups on their development panels, e.g. nurses.

\section{Discussion}

Optimising the care of patients in a financially responsible way is increasingly important in the current era of cancer care. Cancer treatment costs can influence treatment decisions by patients, and subsequently, can affect patient outcomes (46).

The issue of addressing price transparency is global and important in all healthcare systems, including those in countries with universal health care coverage. In the United States, the 'Executive Order on Improving Price and Quality Transparency in American Healthcare to Put Patients First' (47) has been proposed to increase price transparency and inform patients about costs of care before they make informed health care decisions. In Australia, the Department of Health released a report supporting informed financial consent (IFC)(48), and education for consumers and specialists regarding the costs of healthcare. The Australian Medical Association and specialist colleges have also supported IFC and the provision to patients of information about medical fees (49).

Research also shows that interventions to address 'pricing failure', i.e., non-disclosure of prices to patients, can reduce waste in healthcare. It has been estimated that greater transparency about pricing for office and laboratory visits in the US could result in healthcare savings of \$29 billion USD (50).

Limited information is contained in the guidelines for oncologists; however, there are some key recommendations that appear consistently: 1 . Clinician awareness of price variability between treatment options, insurance coverage and geographical regions; 2 . Screening for financial stress as a cause of psychological distress, especially in high risk groups such as low socioeconomic status populations and ethnic minority groups; 3 . Referral to practical supports and services to alleviate financial burden. 
The findings of our systematic review reveal a paucity of information for clinicians about communication regarding the costs of treatment, recognition of financial burden, and the management of patients' financial burden. Most guidelines recommended costs be considered and discussed. However, there was little information to guide these discussions in the clinical setting. In addition, although there were recommendations to refer patients to support services, there was limited information about how or where to find these support services.

Clinicians have described multiple barriers to discussing costs, primarily time constraints and perceived absence of viable solutions if costs are a concern $(51,52)$. Provision of information regarding costs and support services within guidelines may reduce these barriers and facilitate the discussion in the clinical setting. In addition, incorporation of multi-disciplinary team members such as nurses, social workers, counsellors, and pharmacists as referral services for patients to discuss costs and financial concerns may assist management. An outline of questions that providers can consider asking their patients during the initial and follow-up consultations is provided in Table 2.

Table 2

A guide for clinicians to improve cost communication

\begin{tabular}{|c|c|c|}
\hline Time & Costs of care & Financial burden \\
\hline $\begin{array}{l}\text { At initial } \\
\text { appointment }\end{array}$ & $\begin{array}{l}\text { Discuss options of therapy, with } \\
\text { estimates of costs } \\
\text { Provide information on fees to attend } \\
\text { services, e.g., healthcare appointments, } \\
\text { hospital services }\end{array}$ & $\begin{array}{l}\text { Discuss patient employment, } \\
\text { insurance coverage and householc } \\
\text { income status } \\
\text { Suggest local and national } \\
\text { support services if available } \\
\text { Consider early introduction to } \\
\text { financial navigator to develop a } \\
\text { financial plan }\end{array}$ \\
\hline $\begin{array}{l}\text { At follow-up } \\
\text { appointments }\end{array}$ & $\begin{array}{l}\text { Discuss costs of treatment when } \\
\text { prescribing new therapies } \\
\text { Drescribed therapy } \\
\text { piscuss ability to afford current } \\
\text { Assess for presence of cost-saving } \\
\text { strategies, e.g., skipping doses or } \\
\text { appointments }\end{array}$ & $\begin{array}{l}\text { Screen for presence of } \\
\text { psychosocial issues arising from } \\
\text { financial burden } \\
\text { Explore ability to work and } \\
\text { patient's support network } \\
\text { Consider referral to financial } \\
\text { navigator or counsellor }\end{array}$ \\
\hline
\end{tabular}

This is the first systematic review about information regarding costs of cancer care in published clinical practice guidelines. The literature review included international guidelines with no language restrictions to ensure the generalisability of our findings. We undertook a comprehensive search of guideline databases, including manual searches. These results are particularly valuable for health care professionals caring for patients with cancer, especially oncologists and cancer nurses. They will be of special consideration to cancer societies and organisations that develop and publish these guidelines. 
One limitation of our review is that we restricted it to guidelines about the management of advanced cancers. This is not meant to downplay the considerable financial burden faced by survivors of cancer treated with curative intent, which may also have long-term effects on wellbeing. High medical costs have been reported to cause psychological distress in $34 \%$ of cancer survivors, and disproportionately affect those without insurance (53). Our decision to include only guidelines relating to the management of advanced cancer was to keep the recommendations regarding costs and financial burden consistent with changes in employment and work status. These changes are more likely to be permanent in people with advanced cancers.

Our review demonstrates that there is limited information to guide clinicians on how to discuss the costs and financial impact of cancer treatment with their patients. The study identifies gaps in recommendations and resources that should be used to guide future research and development of guidelines to make this information accessible to clinicians. Future guidelines should contain more information about the optimal timing, frequency, and content of these discussions. In addition, future guidelines should include more advice on how oncologists should explain the costs of care accurately and transparently, along with suggestions to reduce financial burden.

Our review demonstrates a scarcity of information and guidelines from other major cancer networks and countries where the rising costs of cancer therapy are becoming an increasing problem. This review highlights findings from primary studies indicating that starting conversations early about the costs of cancer and its treatment may provide patients with a greater sense of control over their management, and reduce both the incidence and severity of financial burden.

Clinical practice guidelines for discussion about cancer costs could be improved by: first, providing costs estimates to clinicians to enable the discussion of treatment options with patients; second, providing information to clinicians about how to identify individuals at high risk of developing financial burden; and third, discussing strategies and options for management of financial burden, including the provision of details of support services. Further research is needed to assess the acceptability and feasibility of clinician-initiated cost discussions in the clinic setting. Further studies on the facilitators and barriers of communication about costs will allow the development of improved guidelines and increase clinician uptake of the recommendations.

\section{Conclusion}

Current clinical practice guidelines have limited information to guide discussions about the costs of anticancer treatment and the management of financial burden. This limits the ability of patients to control the costs of their cancer management, and of the healthcare team to reduce the incidence and severity of financial burden.

\section{Abbreviations}


ASCO: American Society of Clinical Oncology

NCCN: National Comprehensive Cancer Network

SIGN: Scottish Intercollegiate Guidelines Network

GIN: Guidelines International Network

CMA: Canadian Medical Association

\section{Declarations}

\section{Ethics approval and consent to participate}

Not applicable

\section{Consent for publication}

Not applicable

\section{Competing interests}

The authors declare that they have no competing interests

\section{Funding}

AA is supported by a University of Sydney NHMRC Clinical Trials Centre non-award PhD scholarship. AL is supported by an Australian NHMRC Postgraduate Scholarship (APP1168194), Sydney Catalyst Postgraduate Research Supplementary Scholarship, and Melanoma Institute Australia Postgraduate Research Scholarship (top up award). RLM is supported by an Australian NHMRC Translating Research into Practice (TRIP) Fellowship (APP1150989) and a University of Sydney Robinson Fellowship.

\section{Authors' contributions}

AA conducted the literature search. AA and DK read each abstract independently, screened the titles and abstracts for inclusion and finalised the articles to be included in the review. AA and AL conducted the quality assessment for the included guidelines. AA prepared the initial manuscript. AL, DK, MS and RLM critically revised and reviewed the manuscript. All authors commented on the full draft and approved the final manuscript.

Acknowledgements

None reported

\section{Acknowledgement of research support}


AA is supported by a University of Sydney NHMRC Clinical Trials Centre non-award PhD scholarship. AL is supported by an Australian NHMRC Postgraduate Scholarship (APP1168194), Sydney Catalyst Postgraduate Research Supplementary Scholarship, and Melanoma Institute Australia Postgraduate Research Scholarship (top up award). RLM is supported by an Australian NHMRC Translating Research into Practice (TRIP) Fellowship (APP1150989) and a University of Sydney Robinson Fellowship.

\section{References}

1. Mariotto AB, Feuer EJ, Robin Yabroff K, Brown ML, Shao Y. Projections of the cost of cancer care in the United States: 2010-2020. JNCI. 2011;103(2):117-28.

2. Sam D, Cheung WY. A population-level comparison of cancer-related and non-cancer-related health care costs using publicly available provincial administrative data. Curr Oncol. 2019;26(2):94-7.

3. Knight TG, Deal AM, Dusetzina SB, Muss HB, Choi SK, Bensen JT, et al. Financial toxicity in adults with cancer: adverse outcomes and noncompliance. J Oncol Pract. 2018:Jop1800120.

4. Bestvina CM, Zullig LL, Rushing C, Chino F, Samsa GP, Altomare I, et al. Patient-oncologist cost communication, financial distress, and medication adherence. J Oncol Pract. 2014;10(3):162-7.

5. Weaver KE, Rowland JH, Bellizzi KM, Aziz NM. Forgoing medical care because of cost: assessing disparities in healthcare access among cancer survivors living in the United States. Cancer. 2010;116(14):3493-504.

6. Chino F, Peppercorn J, Taylor DH Jr, Lu Y, Samsa G, Abernethy AP, et al. Self-reported financial burden and satisfaction with care among patients with cancer. Oncologist. 2014;19(4):414-20.

7. Meropol NJ, Schrag D, Smith TJ, Mulvey TM, Langdon RM Jr, Blum D, et al. American Society of Clinical Oncology guidance statement: the cost of cancer care. J Clin Oncol. 2009;27(23):3868-74.

8. Irwin B, Kimmick G, Altomare I, Marcom PK, Houck K, Zafar SY, et al. Patient experience and attitudes toward addressing the cost of breast cancer care. Oncologist. 2014;19(11):1135-40.

9. Bullock AJ, Hofstatter EW, Yushak ML, Buss MK. Understanding patients' attitudes toward communication about the cost of cancer care. J Oncol Pract. 2012;8(4):e50-e8.

10. Warsame R, Kennedy CC, Kumbamu A, Branda M, Fernandez C, Kimball B, et al. Conversations about financial issues in routine oncology practices: a multicenter study. J Oncol Pract. 2019;15(8):e690703.

11. Shih YT, Chien CR. A review of cost communication in oncology: Patient attitude, provider acceptance, and outcome assessment. Cancer. 2017;123(6):928-39.

12. Zafar SY, Chino F, Ubel PA, Rushing C, Samsa G, Altomare I, et al. The utility of cost discussions betweeen patients with cancer and oncologists. Am J Manag Care. 2015;21(9):607-15.

13. Moher D, Liberati A, Tetzlaff J, Altman DG. Preferred reporting items for systematic reviews and meta-analyses: the PRISMA statement. BMJ. 2009;339:b2535.

14. Covidence systematic review software. Veritas Health Innovation, Melbourne, Australia. Available at www.covidence.org [. 
15. Brouwers MC, Kho ME, Browman GP, Burgers JS, Cluzeau F, Feder G, et al. AGREE II: advancing guideline development, reporting and evaluation in health care. CMAJ. 2010;182(18):E839-E42.

16. Yan J, Min J, Zhou B. Diagnosis of pheochromocytoma: a clinical practice guideline appraisal using AGREE II instrument. J Eval Clin Pract. 2013;19(4):626-32.

17. Graham ID, Harrison MB. Evaluation and adaptation of clinical practice guidelines. Evid Based Nurs. 2005;8(3):68-72.

18. Lindsay P, Connor Gorber S, Joffres M, Birtwhistle R, McKay D, Cloutier L. Recommendations on screening for high blood pressure in Canadian adults. Can Fam Physician. 2013;59(9):927-33.

19. Taplitz RA, Kennedy EB, Bow EJ, Crews J, Gleason C, Hawley DK, et al. Outpatient management of fever and neutropenia in adults treated for malignancy: American Society of Clinical Oncology and Infectious Diseases Society of America clinical practice guideline update. J Clin Oncol. 2018;36(14):1443-53.

20. Azzoli CG, Baker S Jr, Temin S, Pao W, Aliff T, Brahmer J, et al. American Society of Clinical Oncology clinical practice guideline update on chemotherapy for stage IV non-small cell lung cancer. J Clin Oncol. 2009;27(36):6251-66.

21. Gilligan T, Coyle N, Frankel RM, Berry DL, Bohlke K, Epstein RM, et al. Patient-clinician communication: American Society of Clinical Oncology consensus guideline. J Clin Oncol. 2017;35(31):3618-32.

22. Hesketh PJ, Kris MG, Basch E, Bohlke K, Barbour SY, Clark-Snow RA, et al. Antiemetics: American Society of Clinical Oncology clinical practice guideline update. J Clin Oncol. 2017;35(28):3240-61.

23. Oktay K, Harvey BE, Partridge AH, Quinn GP, Reinecke J, Taylor HS, et al. fertility preservation in patients with cancer: ASCO clinical practice guideline update. J Clin Oncol. 2018;36(19):1994-2001.

24. Griggs JJ, Mangu PB, Temin S, Lyman GH. Appropriate chemotherapy dosing for obese adult patients with cancer: American Society of Clinical Oncology clinical practice guideline. J Oncol Pract. 2012;8(4):e59-61.

25. Rizzo JD, Brouwers M, Hurley P, Seidenfeld J, Arcasoy MO, Spivak JL, et al. American Society of Clinical Oncology/American Society of Hematology clinical practice guideline update on the use of epoetin and darbepoetin in adult patients with cancer. J Clin Oncol. 2010;28(33):4996-5010.

26. Sohal DPS, Kennedy EB, Khorana A, Copur MS, Crane CH, Garrido-Laguna I, et al. Metastatic pancreatic cancer: ASCO clinical practice guideline update. J Clin Oncol. 2018;36(24):2545-56.

27. Michael JM, Rumble RB, Ethan B, Sebastien JH, Andrew L, Dana R, et al. Optimizing anticancer therapy in metastatic non-castrate prostate cancer: American Society of Clinical Oncology clinical practice guideline. J Clin Oncol. 2018;36(15):1521.

28. Wong SL, Faries MB, Kennedy EB, Agarwala SS, Akhurst TJ, Ariyan C, et al. Sentinel lymph node biopsy and management of regional lymph nodes in melanoma: American Society of Clinical Oncology and Society of Surgical Oncology clinical practice guideline update. J Clin Oncol. 2018;36(4):399-413. 
29. Mohile SG, Dale W, Somerfield MR, Schonberg MA, Boyd CM, Burhenn PS, et al. Practical assessment and management of vulnerabilities in older patients receiving chemotherapy: ASCO guideline for geriatric oncology. J Clin Oncol. 2018;36(22):2326-47.

30. Poznak CV, Somerfield MR, Barlow WE, Biermann JS, Bosserman LD, Clemons MJ, et al. Role of bone-modifying agents in metastatic breast cancer: an American Society of Clinical OncologyCancer Care Ontario focused guideline update. J Clin Oncol. 2017;35(35):3978-86.

31. Forastiere AA, Ismaila N, Lewin JS, Nathan CA, Adelstein DJ, Eisbruch A, et al. Use of larynxpreservation strategies in the treatment of laryngeal cancer: American Society of Clinical Oncology clinical practice guideline update. J Clin Oncol. 2018;36(11):1143-69.

32. Scottish Intercollegiate Guidelines Network (SIGN). Cutaneous melanoma. Edinburgh: SIGN; 2017. (SIGN publication no. 146). [January 2017]. Available from URL: http://www.sign.ac.uk.

33. Howell D, Currie S, Mayo S, Jones G, Boyle M, Hack T, et al. A pan-Canadian clinical practice guideline: assessment of psychosocial health care needs of the adult cancer patient. Canadian Partnership Against Cancer (Cancer Journey Action Group) and the Canadian Association of Psychosocial Oncology, May 2009.

34. Howell DKH, Esplen MJ, Hack T, Hamel M, Howes J, Jones J, et al. A pan-Canadian practice guideline: screening, assessment and care of psychosocial distress, depression, and anxiety in adults with cancer. Canadian Partnership Against Cancer and the Canadian Association of Psychosocial Oncology, July 2015.

35. Howell DOT, Keller-Olaman S, Davidson J, Garland S, Samuels C, Savard J, et al. A pan-Canadian practice guideline: prevention, screening, assessment and treatment of sleep disturbances in adults with cancer. Canadian Partnership Against Cancer (Cancer Journey Advisory Group) and the Canadian Association of Psychosocial Oncology, December 2012.

36. National Comprehensive Cancer Network. Distress management (Version 3.2019) 2019 [Available from: https://www.nccn.org/professionals/physician_gls/pdf/distress.pdf.

37. National Comprehensive Cancer Network. Older adult oncology. (Version 1. 2019) 2019 [Available from: https://www.nccn.org/professionals/physician_gls/pdf/senior.pdf.

38. National Comprehensive Cancer Network. Palliative care (Version 2.2019) [Available from: https://www.nccn.org/professionals/physician_gls/pdf/palliative.pdf.

39. Giordano SH, Temin S, Kirschner JJ, Chandarlapaty S, Crew JR, Davidson NE, et al. Systemic therapy for patients with advanced human epidermal growth factor receptor 2-positive breast cancer: American Society of Clinical Oncology clinical practice guideline. J Clin Oncol. 2014;32(19):207899.

40. Andersen BL, DeRubeis RJ, Berman BS, Gruman J, Champion VL, Massie MJ, et al. Screening, assessment, and care of anxiety and depressive symptoms in adults with cancer: an American Society of Clinical Oncology guideline adaptation. J Clin Oncol. 2014;32(15):1605-19.

41. Scottish Intercollegiate Guidelines Network (SIGN). Diagnosis and management of colorectal cancer. Edinburgh: SIGN; 2011. (SIGN publication no. 126). [December 2011]. Available from URL: 
http://www.sign.ac.uk.

42. Scottish Intercollegiate Guidelines Network (SIGN). Management of epithelial ovarian cancer. Edinburgh: SIGN; 2013. (SIGN publication no. 135). [November 2013]. Available from URL: http://www.sign.ac.uk.

43. Scottish Intercollegiate Guidelines Network (SIGN). Management of lung cancer. Edinburgh: SIGN; 2014. (SIGN publication no. 137). [February 2014]. Available from URL: http://www.sign.ac.uk.

44. Scottish Intercollegiate Guidelines Network (SIGN). Management of adult testicular germ cell tumours. Edinburgh: SIGN; 2011. (SIGN publication no. 124). [March 2011]. Available from URL: http://www.sign.ac.uk.

45. Macmillan Cancer Support. [Available from: https://www.macmillan.org.uk/.

46. Greenup RA, Rushing C, Fish L, Campbell BM, Tolnitch L, Hyslop T, et al. Financial Costs and burden related to decisions for breast cancer surgery. J Oncol Pract. 2019;15(8):e666-e76.

47. Executive Office of the President. Improving price and quality transparency in American healthcare to put patients first. Office of the Federal Register, Executive Office of the President. 2019. Report No.: 13877 Contract No.: 84 FR 30849.

48. Ministerial Advisory Committee on Out-of-Pocket costs: Department of Health; 2018 [Available from: https://www1.health.gov.au/internet/main/publishing.nsf/Content/min-advisory-comm-out-ofpocket.

49. Informed Financial Consent - 2015: Australian Medical Association; 2015 [Available from: https://ama.com.au/position-statement/informed-financial-consent-2015.

50. Shrank WH, Rogstad TL, Parekh N. Waste in the US health care system: estimated costs and potential for savings. JAMA. 2019;322(15):1501-09.

51. Alexander GC, Casalino LP, Tseng CW, McFadden D, Meltzer DO. Barriers to patient-physician communication about out-of-pocket costs. J Gen Int Med. 2004;19(8):856-60.

52. Aakhus E, Rosenstein A, Joffe S, Bradbury AR. Implementing cost transparency in oncology: a qualitative study of barriers, facilitators, and patient preferences. J Clin Oncol. 2017;35(15_suppl):6597.

53. Kuehn B. Surviving cancer costs: news from the Centers for Disease Control and Prevention. JAMA. 2019;322(4):297.

\section{Figures}




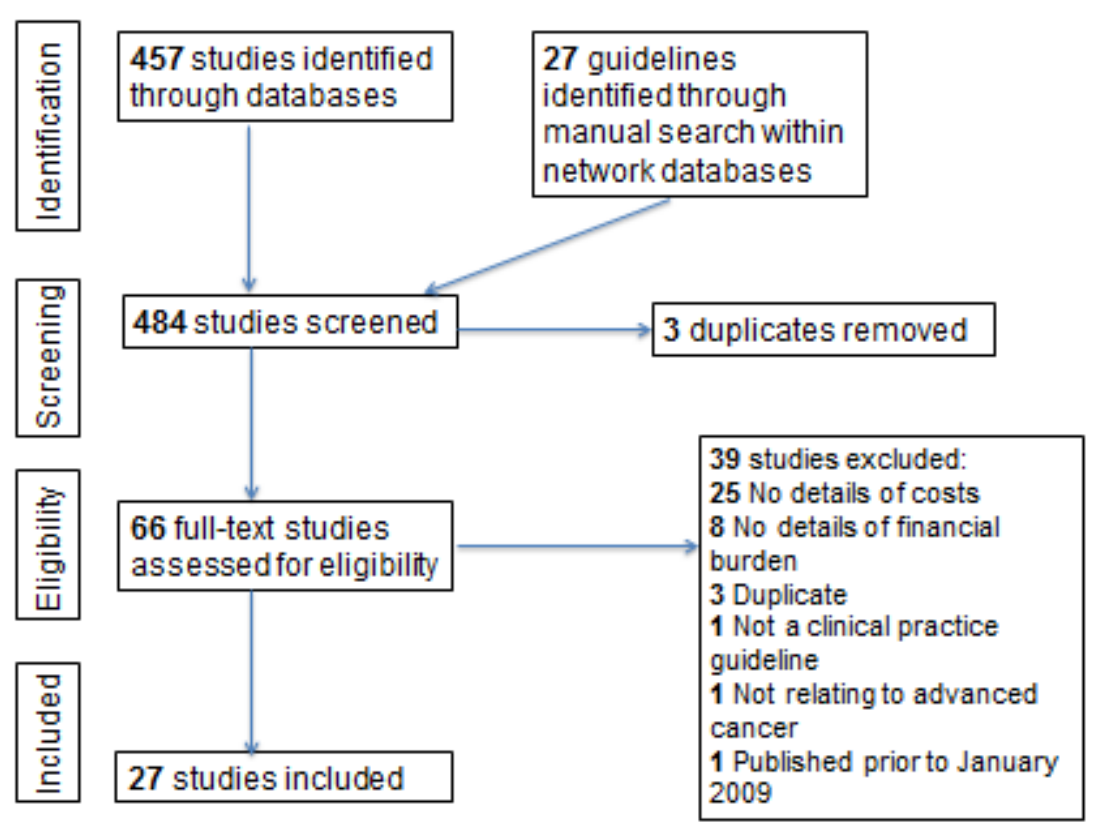

Figure 1

PRISMA Flowchart 


\begin{tabular}{|c|c|}
\hline \multicolumn{2}{|l|}{ Cost } \\
\hline $\begin{array}{l}\text { Theme: Provision } \\
\text { of cost information }\end{array}$ & $\begin{array}{l}\text { - Patient-physician discussions regarding the cost of care are an important } \\
\text { component of high-quality care. Health care providers to include direct and } \\
\text { indirect costs in their discussions with patients. } \\
\text { - Provision of estimated costs to inform clinicians when making decisions or } \\
\text { discussing options of therapy with patients } \\
\text { - Discussions should address high costs of treatment. }\end{array}$ \\
\hline $\begin{array}{l}\text { Theme: Cost } \\
\text { reduction }\end{array}$ & $\begin{array}{l}\text { - Identify areas of cost reduction or cost-related barriers. } \\
\text { - Cost reduction can be addressed by minimising time away from work, altering } \\
\text { schedules and using lower priced options. }\end{array}$ \\
\hline $\begin{array}{l}\text { Theme: Awareness } \\
\text { of price variability }\end{array}$ & $\begin{array}{l}\text { - Medications that are required to be filled at a pharmacy can result in higher out- } \\
\text { of-pocket costs. } \\
\text { - Medication prices vary markedly, depending on negotiated discounts and } \\
\text { rebates as well as between pharmacies. } \\
\text { - Actual treatment costs vary across regions, payers, institutions and practices as } \\
\text { well as over time. Clinicians should consult current local cost information. }\end{array}$ \\
\hline \multicolumn{2}{|c|}{ Detecting financial burden } \\
\hline $\begin{array}{l}\text { Theme: Screening } \\
\text { for financial } \\
\text { concern }\end{array}$ & $\begin{array}{l}\text { - Clinicians should explore whether cost of care is a concern for patients. } \\
\text { - Patients should be asked about financial concerns by their caregivers. }\end{array}$ \\
\hline $\begin{array}{l}\text { Theme: Cause of } \\
\text { psychosocial } \\
\text { distress }\end{array}$ & $\begin{array}{l}\text { - Increasing cancer care costs can affect the psychosocial well-being of patients, } \\
\text { and this should be explored in patients presenting with anxiety, depression or } \\
\text { psychosocial distress. } \\
\text { - Risk factors for distress include financial problems. }\end{array}$ \\
\hline $\begin{array}{l}\text { Theme: Changes in } \\
\text { social status }\end{array}$ & $\begin{array}{l}\text { - A cancer diagnosis may have substantial impact on the employment status of } \\
\text { patients and their families. This can lead to financial burden. } \\
\text { - Patients with cancer can face extreme financial toxicity or bankruptcy and these } \\
\text { financial effects can lead to decreased mortality. }\end{array}$ \\
\hline $\begin{array}{l}\text { Theme: High risk } \\
\text { groups }\end{array}$ & $\begin{array}{l}\text { Members of some racial and ethnic minority groups and patients with fewer } \\
\text { financial resources tend to have higher burden of comorbid illness and are likely } \\
\text { to be uninsured or underinsured. } \\
\text { - Financial worries in cancer survivors may be more common in patients who are } \\
\text { younger, uninsured, have a lower income, and were treated recently. It is } \\
\text { important for the primary oncology team to be aware of the potential financial } \\
\text { worries facing patients undergoing distress screening. }\end{array}$ \\
\hline \multicolumn{2}{|c|}{ Management of financial burden } \\
\hline Practical supports & $\begin{array}{l}\text { - Refer for practical support, e.g., accommodation, transportation, financial } \\
\text { assistance, child/elder care, employment advice, to manage disability. } \\
\text { - Discuss returning to work and insurance issues. } \\
\text { - Advise patients where they can receive information and support for financial } \\
\text { issues, e.g., MacMillan Cancer Support. }\end{array}$ \\
\hline $\begin{array}{l}\text { Referral to } \\
\text { counsellor }\end{array}$ & $\begin{array}{l}\text { - For patients who are concerned about costs of care, clinicians should clarify the } \\
\text { specific concerns and address them directly or by referral to a financial } \\
\text { counsellor or social worker. } \\
\text { - Offer financial counselling to patients with financial concerns to address this } \\
\text { complex and heterogeneous landscape. }\end{array}$ \\
\hline
\end{tabular}

\section{Figure 2}

\section{Supplementary Files}

This is a list of supplementary files associated with this preprint. Click to download. 
- SupplementaryMaterials.docx

Page 19/19 